\title{
Charophyte variation in sensitivity to eutrophication affects their potential for the trophic and ecological status indication
}

\author{
Agnieszka Kolada* \\ Institute of Environmental Protection - National Research Institute, Department of Freshwater Protection, Krucza 5/11D, 00-548 Warsaw, \\ Poland
}

Received: 9 June 2021 / Accepted: 23 July 2021

\begin{abstract}
Charophytes (stoneworts) form a group of macrophytes that are considered sensitive to eutrophication. The high indicator value of charophytes toward eutrophication results in their wide use in the bioassessment systems. I explored the variability of stonewort communities' requirements for trophic conditions in lowland temperate lakes and attempted to determine the role of individual syntaxa in assessing the ecological status of lakes in Poland. The position of charophyte communities' niches along the trophic gradient was analysed using the Outlying Mean Index approach. A few stonewort communities, i.e., Nitelletum opacae, N. mucronatae, N. flexilis and Charetum filiformis appeared to be specialised concerning water quality and may be considered indicators of habitats less eutrophic than the "mean" trophic conditions in the study domain. Most stonewort communities were relatively common in European waters. Four of them, i.e., Charetum tomentosae, C. asperae, C. contrariae and Nitellopsidetum obtusae, can be classified as 'generalists' with low marginality and broad ecological tolerance. Most stonewort communities appeared in a broad range of ecological status classes. In the case of 15 communities, 6 to $25 \%$ of occurrences were observed in lakes representing a less than good status, and they cannot be considered indicative of good ecological conditions. However, the high taxonomic diversity and extensive phytolittoral zone were most likely to occur when the phytocoenoses of stoneworts were present. In lowland naturally eutrophic lakes inhabited by eurytopic species, the extraordinary role of charophytes in the assessment of the ecological status can be interpreted through their significant contribution to the development of the littoral.
\end{abstract}

Keywords: Charophytes / niche position / Outlying Mean Index / eutrophication / ecological status

Résumé - La variation de la sensibilité des charophytes à l'eutrophisation affecte leur potentiel d'indication de l'état trophique et écologique. Les charophytes forment un groupe de macrophytes qui sont considérés comme sensibles à l'eutrophisation. La valeur indicatrice élevée des charophytes vis-à-vis de l'eutrophisation entraîne leur large utilisation dans les systèmes de bioévaluation. J'ai exploré la variabilité des exigences des communautés de charophytes en matière de conditions trophiques dans les lacs tempérés de plaine et ai tenté de déterminer le rôle des relations individuelles dans l'évaluation du statut écologique des lacs en Pologne. La position des niches des communautés de charophytes le long du gradient trophique a été analysée à l'aide de l'approche OMI (Outlying Mean Index). Quelques communautés charophytes, c'est-à-dire Nitelletum opacae, N. mucronatae, N. flexilis et Charetum filiformis, ont semblé être spécialisées en ce qui concerne la qualité de l'eau et peuvent être considérées comme des indicateurs d'habitats moins eutrophes que les conditions trophiques «moyennes» dans le domaine d'étude. La plupart des communautés de charophytes étaient relativement communes dans les eaux européennes. Quatre d'entre elles, à savoir Charetum tomentosae, C. asperae, C. contrariae et Nitellopsidetum obtusae, peuvent être classées comme «généralistes» avec une faible marginalité et une large tolérance écologique. La plupart des communautés de charophytes sont présentes dans un large éventail de classes d'état écologique. Dans le cas de 15 communautés, 6 à $25 \%$ des occurrences ont été observées dans des lacs représentant un état moins que bon, et elles ne peuvent être considérées comme indicatrices de bonnes conditions écologiques. Cependant, la grande diversité taxonomique et l'étendue de la zone phytolittorale étaient plus susceptibles de se rencontrer lorsque les phytocénoses de charophytes

\footnotetext{
*Corresponding author: akolada@ios.edu.pl
} 
étaient présentes. Dans les lacs de plaine naturellement eutrophes où vivent des espèces eurytopiques, le rôle particulier des charophytes dans l'évaluation du statut écologique peut être interprété à travers leur contribution significative au développement du littoral.

Mots clés : Charophytes / position de niche / analyse OMI / eutrophisation / statut écologique

\section{Introduction}

Charophytes, commonly termed "stoneworts", form a heterogeneous group of freshwater green macroalgae, which includes species from the genera Chara, Nitella, Nitellopsis, Tolypella and Lychnothamnus (Dąmbska, 1964; Krause, 1997; Pełechaty and Pukacz, 2008; Urbaniak and Gąbka, 2014). Despite their taxonomic affiliation to algae, due to their large size and thalli morphology, which is reminiscent of vascular plants, charophytes are commonly included with angiosperms under the category "macrophytes" in bioassessment systems developed under the provisions of the Water Framework Directive (WFD, 2000/60/WE; Poikane et al., 2018).

Stoneworts are considered one of the most sensitive groups of macrophytes and their presence is generally indicative of non- or only slightly disturbed conditions (Krause, 1981; Schwarz et al., 1999; van den Berg, 1999; van Donk and van de Bund, 2002). Accelerating eutrophication poses a serious threat to charophytes, which is reflected by their migration from the deepest parts of the littoral to shallower zones, followed by rapid decline until complete extinction (Ozimek and Kowalczewski, 1984; van den Berg, 1999; van den Berg et al., 1999; Blindow et al., 2002; Kolada, 2010). A clear negative effect of anthropogenic pressure on the occurrence, biomass and colonisation depth of these plants has led to the widespread use of charophytes as bioindicators in ecological status assessment in many countries (Portielje et al., 2014; Poikane et al., 2018).

Although commonly considered indicative of high water quality, in fact, stoneworts may inhabit a wide spectrum of nutrient concentrations (Blindow, 1988; Blindow, 1992; Kufel and Ozimek, 1994; Kufel and Kufel, 2002) and light conditions (Schwarz et al., 2002). Their presence has been reported even in highly eutrophicated lakes, artificial channels or reservoirs (Crawford, 1977; Baastrup-Spohr et al., 2013). Several studies noted a high abundance of Chara at high nutrient concentrations and therefore questioned their indicator value (Søndergaard et al., 2010).

Due to the considerable intra-specific heterogeneity of charophytes in terms of habitat requirements (Baastrup-Spohr et al., 2013, 2015; Rey-Boissezon and Auderset Joye, 2015), the indication value of individual species toward both eutrophication and the ecological status of an ecosystem may vary substantially. This variability raises the question of the utility of stoneworts as indicators of lake ecological status, especially with respect to the position of individual charophyte taxa along the eutrophication gradient.

To recognise the taxonomic variability and the diversity of the habitat requirements of stoneworts inhabiting lakes in Poland, I explored the extensive national monitoring dataset, which comprises floristic and environmental data from over 500 lakes and over 700 lake surveys from the years 2005-2015. I attempted to determine the environmental conditions in which different species of charophytes form communities in temperate lowland lakes located on postglacial deposits with highly buffered waters, naturally meso- and eutrophic, which are exposed to eutrophication pressure. Since macrophyte monitoring in Poland employs the synecological approach (Braun-Blanquet, 1964), in this study plant communities, not species, were considered. The term 'community' (syntaxon) was used for homogenous and uniform vegetation stands (phytocoenoses sensu Westhoff and van der Maarel, 1973, after Jensen, 1977), named after the dominating species. In fact, charophyte stands are almost unexceptionally monospecific, which makes distinguishing between species (autecology) and communities (synecology) not that relevant as it is for, e.g., terrestrial vegetation.

To determine the position of charophyte communities in the eutrophication gradient, I used the Outlying Mean Index approach (OMI; Dolédec et al., 2000). The OMI is a multivariate analysis designed to study the niche position along multiple environmental gradients. This method enables the exploration of the mean environmental conditions of the species occurrence (niche separation) and variance around the niche position (niche breadth). It was demonstrated to be a useful tool to characterise the environmental occupancy of different groups of terrestrial and aquatic organisms, i.e., jaguars and pumas in South America (Palomares et al., 2016), mouse species belonging to the genus Rhabdomys inhabiting the Southern African subregion (Meynard et al., 2012), the plants of grazed grasslands in Northeast Germany (Kleyer et al., 2012) or shrubs from the genus Leucadendron in the Cape Floristic region in South Africa (Thuiller et al., 2004). For aquatic vegetation, this approach has been applied by Baastrup-Spohr et al. (2015) and Rey-Boissezon and Auderset Joye (2015) to test the charophyte niche separation and breadth in Danish and Swiss lakes, respectively. Those studies addressed ecosystems representing considerably less eutrophied conditions compared to the lakes typical of the Central European Lowlands analysed in this study. Although the effect of eutrophication on charophytes has been well-documented, the performance of stonewort taxa in lowland temperate lakes with relatively short trophic gradients (spanning from mesotrophy to hypertrophy) and their contributions to ecological status assessment under eutrophic conditions have been less explored. Following the considerations of Rey-Boissezon and Auderset Joye (2015), this study should not be termed "niche analysis" but "habitat analysis", as it addresses the physicochemical features of the location where a species survives and reproduces (habitat), without taking into account the morphological, physiological and behavioural evolutionary adaptations of a species to the local conditions (niche).

This study provides a comprehensive overview of the diversity, performance and habitat requirements of charophytes inhabiting Polish lowland lakes that are monitored under the Water Framework Directive requirements (WFD; 
EU, 2000/60/EU). This research was particularly aimed at exploring the utility of the indication value of charophytes from the perspective of ecological status assessment. Ultimately, I intended to explore how likely it is that the presence of charophytes corresponds to a better ecological status of an ecosystem compared with lakes not inhabited by stoneworts and whether all charophyte taxa can be considered indicators of high ecological quality.

\section{Material and methods}

\subsection{Data collection}

Data on macrophytes and water physicochemistry collected in the years 2005-2015 from 504 lakes were analysed. The database comprised 739 lake surveys, with discrete surveys for 318 lakes and repeated surveys for 186 lakes with two (149 lakes) to five (2 lakes) replicates for a lake. All of the studied lakes are lowland $(<240 \mathrm{~m}$ a.s.1.), with medium to high alkalinity (0.2-9.1 meq L $\left.{ }^{-1}\right)$ non-coloured waters, representing various hydromorphological and trophic conditions (Tab. S1 in the Supplementary Material). Data on macrophytes were collected within the state monitoring programme (680 surveys during the period 2007-2015), the Polish-Norwegian Research Fund (PNRF) project 'deWELopment' (11 lakes surveyed in 2009; Kolada et al., 2014a) and other research projects (49 lakes surveyed from 2005-2006; Ciecierska and Kolada, 2014; Kolada et al., 2014b).

All lakes were investigated for macrophytes using the unified field survey procedure based on the belt transect method (Ciecierska and Kolada, 2014; Kolada et al., 2014a). The method consists of the transect survey, where observations of aquatic vegetation are made along 30-m-wide belt transects set perpendicularly to the shoreline and covering the entire vegetated zone, from the upper eulittoral to the outer limit of macrophyte growth. From 6 to 80 transects were established on each lake depending on its size and perimeter (Jensen, 1977), and they were evenly distributed along the shoreline. The observations were made by wading and boating with the use of a rake and a bathyscope. At each transect, the maximum colonisation depth, the total vegetation coverage and the relative cover of all the submerged, floating-leaved and emergent plant communities were determined. Data from all transects within a lake were recalculated afterwards to a lake level, i.e., averaged maximum colonisation depth, mean vegetation coverage, complete list of syntaxa identified within all transects and relative abundance of each syntaxon in a total area vegetated ( $\%$ area occupied summing up to $100 \%)$ (Ciecierska and Kolada, 2014). Ultimately, one lake-survey comprises a complete inventory of aquatic and rush vegetation within a phytolittoral in a given year constituting discreet and independent survey.

For the identification and classification of aquatic and rush vegetation, the phytosociological approach was applied (Braun-Blanquet, 1964), i.e., plant communities, not species, are considered. This means that plant units are recorded as long as they create stands with an area of at least $1 \mathrm{~m}^{2}$. For the vascular plant communities, the syntaxonomic systems established by Brzeg and Wojterska (2001) and Matuszkiewicz (2002) were adopted. For stonewort communities, the botanical nomenclature, classification system and the terminology as proposed by Pełechaty and Pukacz (2008) and Urbaniak and Gąbka (2014) were used (Tab. S2). In the syntaxonomic systems, 'association' is considered the basic unit, comparable to species in taxonomy. Plant association is defined as an abstract vegetation unit ('plant community') that has a definite floristic composition and uniform physiology, and occurs in uniform habitat conditions (Flahaut and Schröter, 1910 after Willner, 2006). Syntaxon names are formed of the scientific names of one or two plant species or infraspecific taxa, which usually are characteristic for the community. The scientific syntaxon names involves connecting vowels, relevant termination indicating syntaxonomic rank (-etum in the case of associations), and the declination of the taxon epithets (Dengler et al., 2008). In the syntaxonomic system referred to, many stonewort communities are in a rank of 'association'. In this study, however, I systematically use the term 'community' to avoid confusion between the terms 'community' and 'association'.

Environmental data used in the study included the seasonal mean of the $\mathrm{pH}$, alkalinity, total phosphorus (TP), total nitrogen (TN), chlorophyll $a$ concentration (Chl- $a$ ) and Secchi disk depth (SD). Lakes were sampled for water quality in the same year as the vegetation surveys were conducted, in most cases four times during the vegetation season, from March to October (spring mixing, early summer, the peak of the summer stagnation and autumn mixing). Water samples were taken from the deepest part of a lake, although lakes with a large surface area were usually sampled at two to five sites. During the summer stagnation period, integrated water samples were collected from the epilimnion layer and in spring and autumn, from the euphotic layer. In non-stratified lakes, integrated samples were taken from the layer between $0-5 \mathrm{~m}$. Data on the water quality of 11 lakes were collected within the PNRF project 'deWELopment' (Soszka and Ochocka, 2011), while data for the other lakes used in the study were collected within the state monitoring programme.

\subsection{Data processing}

In the analysed lakes, 128 macrophyte communities were recorded, of which 20 communities were formed by charids (Tab. S2). The position of charophyte communities along the eutrophication gradient (trophic ranking) was analysed using the Outlying Mean Index method (OMI; Dolédec et al., 2000). This method seeks combinations of environmental variables that maximise the average species marginality, i.e., the squared Euclidean distance between the mean habitat conditions used by a species and the mean habitat conditions of the sampling area (Karasiewicz et al., 2017). The advantage of the OMI is that it makes no assumption concerning the shape of the species response curve to the environment, and it gives equal weight to species-rich and species-poor sites (Dolédec et al., 2000; Kleyer et al., 2012). The OMI analysis employs environmental gradients provided by Principal Component Analysis (PCA). The environmental gradients used in this study were based on the main eutrophication parameters, i.e., $\mathrm{TP}, \mathrm{TN}, \mathrm{SD}, \mathrm{Chl}-a, \mathrm{pH}$ and alkalinity, as water quality was the primary driver addressed in this study. Data on TP, TN SD and Chl- $a$ were $\log _{10}$ transformed prior to the analysis to comply 
with the normality assumption and to avoid heteroscedasticity. Only hydrophyte communities that appeared in more than three lakes were further analysed, which reduced the number of charophyte communities to 17 , all hydrophyte communities to 65 and lake years to 692 . The position of charophyte communities among other hydrophytes and their rank along the eutrophication gradient were analysed. The community relative abundance (relative cover) was used as the response variable.

For all communities, the Outlying Mean Index (OMI), the Tolerance Index (Tol) and the residual tolerance (Rtol) were calculated. An index OMI measures the marginality of species, or the distance between the average environmental conditions used by a species and the mean environmental conditions of the sampling units of the study area. Ecologically, species with high OMI values have marginal niches (i.e., occur in less common habitats in the studied region), while those with low values have non-marginal niches (i.e., occur in typical habitats in the region) (Hernández-Fariñas et al., 2015; Palomares et al., 2016). The species tolerance (Tol) is a measure of niche breath, i.e., the dispersion from the mean of the environmental variables used by a species (Dolédec et al., 2000). High tolerance values indicate that the species is distributed along a variety of environmental conditions, while low values imply that the species is distributed along a more limited range of environmental conditions. The residual tolerance indicates the proportion of variability in the habitat that is not explained by measured variables. Its low values indicate that the relationship between the study's environmental conditions and the species distribution is high, whereas high values indicate that they are weakly related (Dolédec et al., 2000; Palomares et al., 2016). The significance of the determined niche position was tested using the Monte-Carlo permutation test under the null model with 1,000 permutations. The OMI analysis was performed using functions provided by the packages "ade4" and " $k n i t r$ " in $\mathrm{R}$ software ver. 3.4.4., and the scripts provided by Kleyer et al. (2012) and Karasiewicz (2018) were applied.

The effect of charophyte diversity, hence, the variability in the tolerance to environmental conditions on bioassessment results, was tested using the Ecological State Macrophyte Index (ESMI; Ciecierska and Kolada, 2014). This method makes no a priori assumptions about the effect of the presence and abundance of charophytes on the assessment result. The index is composed of two components, the composition metric J (Pielou's index of evennness) and the abundance metric $Z$ (colonisation index). The index of evenness $\mathrm{J}$ is the ratio of the phytocenotic diversity index $H$ and the maximum diversity index $H_{\max }$, calculated at the community level. The colonisation index $Z$ is a derivative of the maximum colonisation depth $\left(C_{\max }\right)$ and macrophyte coverage, and expresses the extent of the phytolittoral zone, indicating whether the area inhabited by plants is smaller than $(Z<1)$, equal to $(Z=1)$ or higher than $(Z>1)$ the area of a lake where the water is shallower than $2.5 \mathrm{~m}$. The reliability of assessment results produced by ESMI and the comparability of classification with other European macrophytic methods have been confirmed in the pan-European intercalibration process (Portjelie et al., 2014). Methodological details and classification system of ESMI can be found in Ciecierska and Kolada (2014) and Portjelie et al. (2014).
The effect of the charophyte syntaxonomic diversity and abundance on ecological status classification results determined by ESMI were analysed with descriptive statistics, using STATISTICA ver. 10 (StatSoft, 2011).

\section{Results}

\subsection{Variability of stonewort sensitivity to trophic conditions}

Charophytes were noted in 267 out of 504 lakes (53\%) and in 404 out of 739 lake surveys (55\%), and their occurrence was evenly distributed across the lakeland area in the country (Fig. 1). The number of stonewort communities per lake ranged between 1 and 12, with an average of 2.8. The proportion of the phytolittoral area covered by charophytes (\%Chara) ranged from 0.02 to $99.9 \%$, with an average of $27.1 \%$. Twenty communities of stoneworts were identified, including 13 communities formed by representatives of the genus Chara, 5 of Nitella, 1 of Nitellopsis (the only representative is $N$. obtusa) and 1 of Lychnothamnus (the only representative is $L$. barbatus) (Tab. 1). The most frequently observed community in the analysed lakes was Nitellopsidetum obtusae with 303 observations, accounting for $41 \%$ of all surveys in the database $(n=739)$ and $75 \%$ of surveys where Chara-communities were found $(n=404)$. The least frequent were Charetum tenuispinae, $C$. strigosae and Nitelletum syncarpae, recorded in only one or two lakes.

Lakes where charophytes were noted had significantly lower TP, TN and Chl- $a$ concentrations and a higher SD; hence, they were less eutrophic than those not inhabited by charophytes (Tab. S1). However, charophyte communities occurred across the entire range of water trophy analysed in this study (Fig. 2). Though the highest frequency of occurrence $(>50 \%)$ and the highest mean relative coverage of the total littoral area $(>15 \%)$ were found in lakes with TP concentrations $<60 \mu \mathrm{gP} \mathrm{L}^{-1}$, above this threshold stonewort phytocoenoses also appeared systematically (Fig. 2).

The data used in the PCA created two environmental gradients, a strong eutrophication gradient (PCA1, explaining $41.2 \%$ of the overall variation) and a much weaker gradient related to water buffering capacity (PCA2, explaining $17.0 \%$ of the variation) (inset in Fig. 3). The standardised environmental table from the PCA in combination with the floristic data provided two distributions of community niches along the OMI gradients. Along the OMI axis 1, explaining $67.6 \%$ of the niche variance and reflecting the community rank along the trophic gradient, three groups of characean communities were identified (Fig. 3). Communities $N$. mucronatae, $N$. opacae, C. filiformis and $N$. flexilis deviated the most from the mean (ubiquitous) habitat conditions, indicating the highest sensitivity to trophy, while $C$. asperae, $C$. contrariae, C. tomentosae and N. obtusae most approximated the mean conditions, indicating the lowest sensitivity to trophy. All other stonewort communities held intermediate positions in the trophic gradient, exhibiting moderate sensitivity. This pattern of niche positions followed the median values of nutrient concentrations in waters where the communities were reported from, in general (Tab. S3). Along the alkalinity gradient (OMI2, explaining $16.1 \%$ of the 


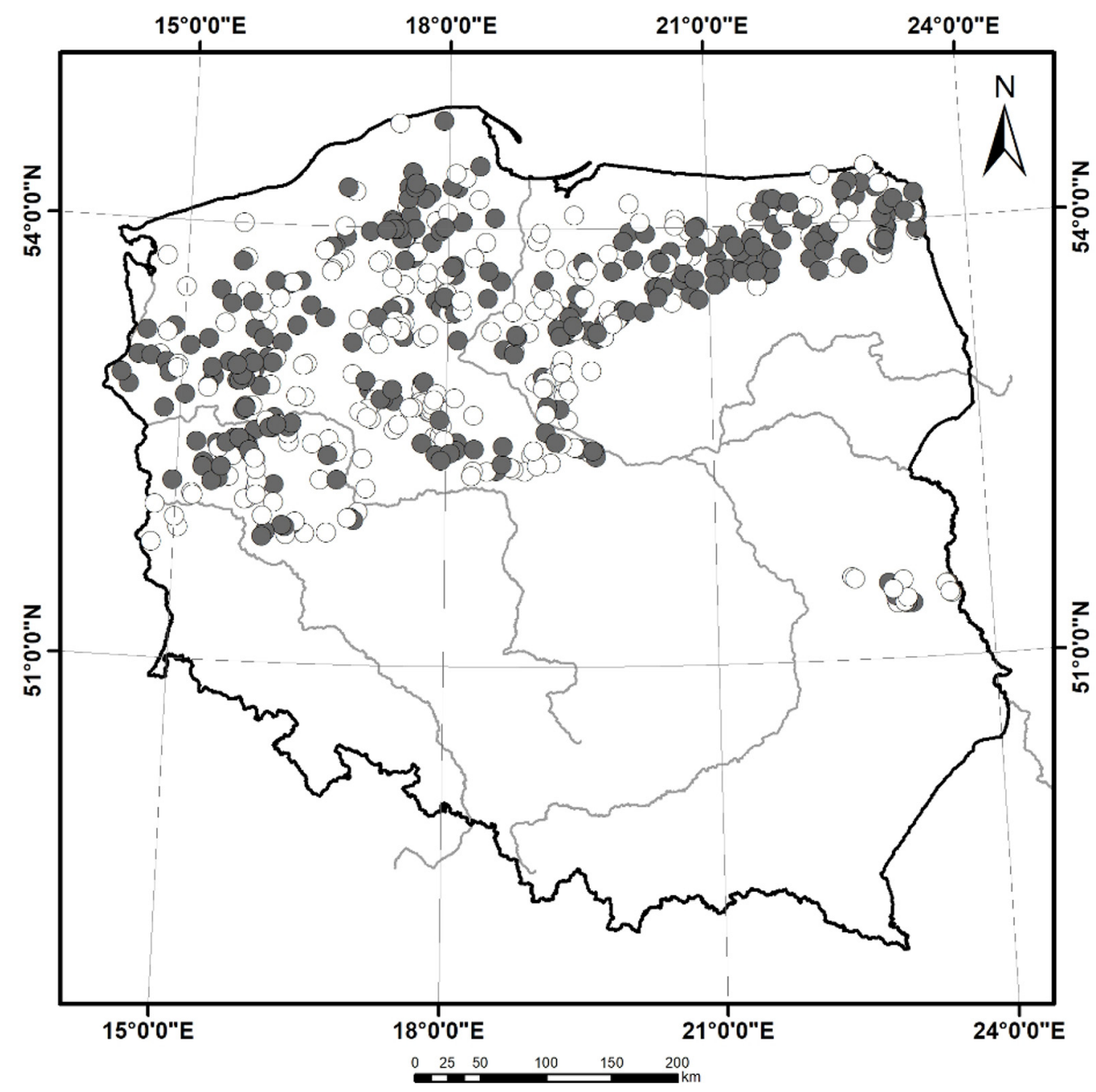

Fig. 1. Distribution of the analysed lakes within the Polish lakelands. Lakes inhabited by charophytes are indicated with full circles $(n=267)$, lakes without charophytes are indicated with open circles $(n=237)$.

variation), the pattern was less pronounced, with $N$. opacae clearly deviating towards the most alkaline waters (median value of alkalinity $2.8 \mathrm{meq} \mathrm{L}^{-1}$ ) and $N$. mucronatae towards the least buffered ones (Fig. 3).

In a pool of all hydrophytes analysed in the study, the OMI gradient spanned between 16.79 for Isoëtetum lacustris Szańk. et Kłos. 1996 n.n. and 0.03 for Ceratophylletum demersi Hild 1956 and Potametum perfoliati (W. Koch 1926) Pass. 1964, while Tol was between 10.35 for Potametum pectinati (Hueck 1931) Carstensen 1955 and 0.01 for Lychnothamnetum barbati (Gołdyn 1984) Brzeg et M.Wojterska 2001 (Tab. S2). The OMI values for the charophyte communities ranged between 8.48 (N. mucronatae), indicating high marginality, and 1.18 (C. tomentosae), pointing to a low marginality. The highest marginality (OMI > 5.0) was attributed to $N$. mucronatae, $N$. opacae, $N$. flexilis and C. filiformis and the lowest $(\mathrm{OMI}<2.0)$ to $N$. obtusae, $C$. tomentosae, $C$. asperae and $C$. contrariae (Tab. 2). The Tol value ranged between 0.01 for $L$. barbati, with the narrowest range of habitats occupied, and 2.22 for C. polyacanthae, and it was also relatively high for C. tomentosae, C. asperae and $N$. gracilis $(\mathrm{Tol}>1.5)$. The position of stonewort niches in the context of all 65 hydrophyte communities in the entire trophic gradient within the study domain ranked within the top half of the communities with the highest marginality (Fig. S1). Thirteen of the 17 analysed stonewort communities were located within the first 20 positions. Stonewort communities that appeared to be least sensitive to trophic conditions, i.e., Nitellopsidetum obtusae, C. tomentosae, C. asperae and C. contrariae, ranked in the middle of the OMI1 gradient derived for all hydrophyte communities.

In a group of all hydrophyte communities $(n=65)$, the relationship between the OMI and Tol was statistically non-significant $(p=0.68)$, which indicates that syntaxa with niches close to "typical" conditions may have a narrow trophic niche and vice versa. The expected relationship between the $\mathrm{OMI}$ and the community frequency of occurrences $(F \%)$ was significant and negative (Spearman $R_{\mathrm{Sp}}=-0.61, p<0.0001$ ), pointing to the high frequency of syntaxa with low marginality (eurytopic) and the low frequency of syntaxa occupying conditions that are rare for the study domain. The significant positive relationship between Tol and $\mathrm{F} \% \quad\left(R_{\mathrm{Sp}}=0.45\right.$, $p<0.0001)$, together with the lack of relationship between the OMI and Tol, indicates that syntaxa with narrow ecological niches tended to appear less frequently than those 
Table 1. List of charophyte communities identified in the analysed lakes $(n=504)$ and lake-surveys $(n=739)$; syntaxa arranged according to the frequency of occurrence $F(\%)$ in descending order.

\begin{tabular}{|c|c|c|c|c|}
\hline Community (syntaxa) & Dominant species & $n$ (lakes) & $n$ (lake-years) & $F(\%) n=739$ \\
\hline $\begin{array}{l}\text { Nitellopsidetum obtusae (Sauer 1937) } \\
\text { Dąmbska } 1961\end{array}$ & $\begin{array}{l}\text { Nitellopsis obtusa (Desvaux in Loiseleur- } \\
\text { Deslongchamps) J. Groves } 1919\end{array}$ & 216 & 303 & 41.0 \\
\hline Charetum tomentosae Corillion 1957 & Chara tomentosa Linné 1753 & 152 & 198 & 26.9 \\
\hline Charetum fragilis Fijałkowski 1960 & $\begin{array}{l}\text { Chara globularis Thuillier } 1799 \text { (=Chara fragilis } \\
\text { Desvaux in Loiseleur-Deslongchamps 1810) }\end{array}$ & 143 & 187 & 25.3 \\
\hline $\begin{array}{l}\text { Charetum delicatulae Doll } 1989 \text { ex } \\
\text { Gąbka et Owsianny } 2010\end{array}$ & Chara delicatula Agardh 1824 & 67 & 82 & 11.1 \\
\hline Charetum asperae Corillion 1957 & Chara aspera Detharding ex Willdenow 1809 & 43 & 53 & 7.2 \\
\hline Charetum contrariae Corillion 1957 & Chara contraria A. Braun ex Kützing 1845 & 40 & 46 & 6.2 \\
\hline Charetum rudis Dąmbska 1966 & Chara rudis A. Braun in Leonhardi 1882 & 38 & 43 & 5.8 \\
\hline Nitelletum flexilis Corillion 1957 & Nitella flexilis (Linné) Agardh 1824 & 32 & 37 & 5.0 \\
\hline Charetum vulgaris Corillion 1957 & Chara vulgaris Linné 1753 & 22 & 27 & 3.7 \\
\hline $\begin{array}{l}\text { Charetum filiformis (Jeschke 1959) } \\
\text { Krausch } 1964 \text { em. Dąmbska } 1966\end{array}$ & $\begin{array}{l}\text { Chara filiformis Hertzsch } 1855(=\text { Chara jubata } \\
\text { A. Braun) }\end{array}$ & 23 & 25 & 3.4 \\
\hline $\begin{array}{l}\text { Charetum intermediae (Corillion } \\
\text { 1957) Fijałkowski } 1960\end{array}$ & $\begin{array}{l}\text { Chara intermedia A. Braun } 1836 \text { (= Chara } \\
\text { aculeolata Kützing in Reichenbach 1832) }\end{array}$ & 23 & 24 & 3.2 \\
\hline Charetum hispidae Corillion 1957 & Chara hispida Linné 1753 & 12 & 13 & 1.8 \\
\hline Nitelletum gracilis Corillion 1957 & Nitella gracilis (Smith) Agardh 1828 & 11 & 12 & 1.6 \\
\hline $\begin{array}{l}\text { Charetum polyacanthae Dąmbska } \\
1966 \text { ex Gąbka et Pełechaty } 2003\end{array}$ & $\begin{array}{l}\text { Chara polyacantha A. Braun in Braun, Rabenhorst } \\
\text { et Stizenberger } 1859\end{array}$ & 11 & 11 & 1.5 \\
\hline $\begin{array}{l}\text { Nitelletum mucronatae Tomaszewicz } \\
\text { ex Hrivnák et al., } 2001\end{array}$ & Nitella mucronata (A. Braun) Miquel 1840 & 6 & 7 & 0.9 \\
\hline Nitelletum opacae Corillion 1957 & Nitella opaca (Bruzelius) Agardh 1824 & 6 & 7 & 0.9 \\
\hline $\begin{array}{l}\text { Lychnothamnetum barbati (Gołdyn } \\
\text { 1984) Brzeg et Wojterska } 2001\end{array}$ & Lychnothamnus barbatus (Meyen) Leonhardi 1863 & 3 & 4 & 0.5 \\
\hline $\begin{array}{l}\text { Charetum tenuispinae Dąmbska } 1966 \\
\text { ex Tomaszewicz } 1979\end{array}$ & Chara tenuispina A. Braun 1835 & 2 & 2 & 0.3 \\
\hline $\begin{array}{l}\text { Nitelletum syncarpae (Corillon 1957) } \\
\text { Dąmbska } 1966\end{array}$ & Nitella syncarpa (Thuillier) Chevalier 1827 & 1 & 1 & 0.1 \\
\hline Charetum strigosae (Dąmbska 1966) & Chara strigosa A. Braun 1847 & 1 & 1 & 0.1 \\
\hline
\end{tabular}

with a broad ecological tolerance (generalists), irrespective of their position in the eutrophication gradient.

\subsection{Effect of stoneworts on bioassessment results}

Although neither the presence nor abundance of charophytes are used per se as assessment criteria in the ESMI method, lakes classified as having high ecological conditions were usually dominated by stoneworts, whereas in lakes classified as good, the abundance of these plants was significantly lower (Fig. 4); only in lakes assessed as bad were stoneworts absent. Of the 72, 318, 248, 90 and 6 lakes classified as high, good, moderate, poor and bad, respectively, $97,75,30,20$ and $0 \%$ were inhabited by charophyte phytocoenoses. Six of the 739 lake surveys were not assessed for ecological status.

Most stonewort communities appeared in various ecological status classes and in the case of 15 of the 17 communities occurring in more than three lakes, 6 to $25 \%$ of the observations were noted in lakes representing a less than good status. Seven communities, which were recognised as the least marginal and most tolerant (Tab. 2), were noticed in lakes with a poor ecological status (Fig. 5). For four charophyte communities with the lowest marginality (OMI $<0.2$, Tab. 2$)$, approximately 2 to $5 \%$ of the observations were found in lakes with a poor status. None of the stoneworts were present exclusively in the high status class, though communities with the highest marginality (OMI $>0.5)$ did not or rarely appeared in lakes assessed as lower than good. Likewise, communities not analysed for niche position due to their incidental occurrence in the database $(n<3)$ were noted in lakes assessed as having a good (C. tenispinae and $C$. strigosae) or high ecological status (N. syncarpae) according to ESMI.

The assessment result of ESMI relies on two main community components, syntaxonomic diversity and abundance; the latter is mirrored by the extent of the littoral. A strong relationship between the macrophyte colonisation depth and \%Chara was found (Spearman's $R_{\mathrm{Sp}}=0.67, p<0.0001$ ), while for submerged vascular plants, this relationship was weaker $\left(R_{\mathrm{Sp}}=0.56, p<0.0001\right)$; for floating-leaved plants it was statistically non-significant $(p=0.15)$, and for helophytes it was strongly negative $\left(R_{\mathrm{Sp}}=-0.69, p<0.0001\right)$. This indicates that lakes with a high abundance of charophytes had a statistically larger phytolittoral zone than those inhabited by vascular plants only. For the phytocenotic diversity, the relationship between \%Chara and $\mathrm{H}$ was slightly weaker $\left(R_{\mathrm{Sp}}=0.47, p<0.0001\right)$ than that between submerged vascular plants and $\mathrm{H}\left(R_{\mathrm{Sp}}=0.51, p<0.0001\right)$, indicating that 

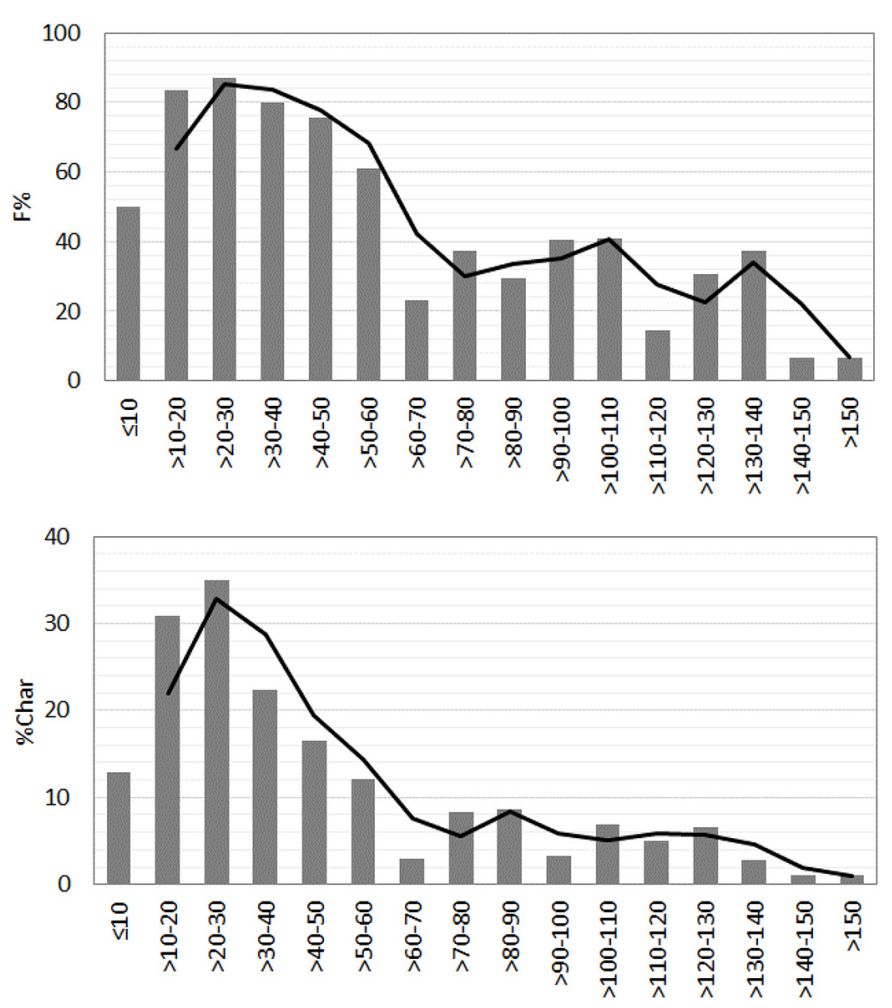

Fig. 2. The frequency of occurrence $(F \%)$ and proportion of the phytolittoral area covered by charophyte communities (\%Chara) in classes of the total phosphorus concentration (TP) in lowland lakes $(100 \%=739$ lake-surveys); solid lines present the moving average trendlines.

lakes with the phytolittoral dominated by stoneworts were taxonomically less diverse than those dominated by vascular plants.

\section{Discussion}

From Polish waters, 34 species of Characeans (including two which are currently considered extinct) have been reported, of which 22 are found in inland waters (Pełechaty and Pukacz, 2008; Urbaniak and Gąbka, 2014). Therefore, the list of taxa analysed in this study includes almost a complete list of the species of this family listed in freshwater bodies in the country. In the analysed database, no communities of Nitella capilaris and $N$. tenuissima or representatives of the genus Tolypella have been recorded, as these species rarely appear in lakes and often do not form communities (Pełechaty and Pukacz, 2008). A similar number of stonewort species has been reported by Baastrup-Spohr et al. (2015) from lakes in Denmark (23 species), Norway (25), Sweden (32) and Finland (20), by Lambert-Servien et al. (2006) from the lakes of the Pays-de-la-Loire region in France (22), by Vesić et al. (2016) from the lakes of the Vojvodina region in Serbia (17) and by Auderset Joye and Rey-Boissezon (2015) from the lakes of Switzerland (21). Thus, the list of taxa analysed in this work can be considered representative for this geographical region of Europe.

According to the results of the OMI analysis, among 20 stonewort species that formed communities in the Polish waters analysed in this study, four appeared to be highly specialised concerning water quality (high marginality, OMI $>5$ and low tolerance, Tol $<1$, at the same time), i.e., N. opacae, N. mucronatae, $N$. flexilis and C. filiformis. Species forming these communities are sensitive to eutrophication (Urbaniak and Gąbka, 2014), with rapid declines observed in European waters (Auderset Joye et al., 2002; Baastrup-Spohr et al., 2013). The presence of these species and their communities may be indicative of conditions distant from those considered "mean" in the analysed region, which are significantly less eutrophic in this case. For the other three associations most rarely found in the analysed lakes, i.e., $N$. syncarpae, C. tenuispinae and C. strigosae, niches could not be modelled due to insufficient frequency (one to two lakes). It is likely that the rare occurrences of these three communities result from their very narrow ecological amplitude (Blaženčić et al., 2006a; Rey-Boissezon and Auderset Joye, 2015) and the limited availability of suitable habitats for their development in Polish lakes. Species that are demonstrated specialists with a high marginality and low tolerance are rare and therefore of special concern. They have a high conservation status and are under protection; they are also listed in the IUCN and in national Red Lists (IUCN, 2001; Baastrup-Spohr et al., 2015; Blaženčić et al., 2006b; Siemińska et al., 2006). Their occurrence in lakes monitored under WFD in Poland is exceptional and unusual and also makes the ecosystems attractive for taxonomists, ecologists and water managers.

One community that is worthy of deeper consideration here is Lychnothamnetum barbati. Its dominant species Lychnothamnus barbatus is considered extremely rare and almost extinct in Europe (Azzella and Abdelahad, 2011; Azzella, 2014; Sugier et al., 2010), and it is also unique in Poland. Unfortunately, due to the insufficient number of observations $(n=4)$, its niche position modelled in this study was insignificant. It is worth mentioning, however, that this community was attributed the lowest Tol of all 17 stonewort communities examined, but its OMI value (marginality) was only the fifth highest (Tab. 2). Therefore, although the habitat conditions where L. barbati occurred were narrow, they were not far from the mean, relatively eutrophic, conditions within the studied area. This suggests that the occurrence of L. barbatus is determined, at least to some extent, by factors other than nutrient concentration. The occurrence of this species in rather eutrophic lakes was also demonstrated by other studies (Pełechaty and Brzozowski, 2016; Brzozowski et al., 2018). Moreover, phytocoenoses of L. barbati tend to coincide with the $N$. obtusae community (Kolada, 2009; Pełechaty et al., 2009; Pełechaty et al., 2014; Brzozowski et al., 2018). The latter, in turn, belongs to the most widely distributed charophyte community in Poland and is relatively tolerant of trophic conditions (Tab. 2). The coexistence of the phytocoenoses of the rarest and the most common species has been explained by the higher shade tolerance and light use efficiency of $L$. barbatus, which tends to occupy deeper sites than tolerant species (Brzozowski et al., 2018). However, the potential inter-species relationships between these two charophyte species deserve further in-depth research.

Most stonewort communities analysed in this study, however, are reported as relatively common in European waters (Blaženčić et al., 2006a; Dąmbska, 1964; Pełechaty and Pukacz, 2008; Rey-Boissezon and Auderset Joye, 2015). Four 
A. Kolada: Knowl. Manag. Aquat. Ecosyst. 2021, 422, 30

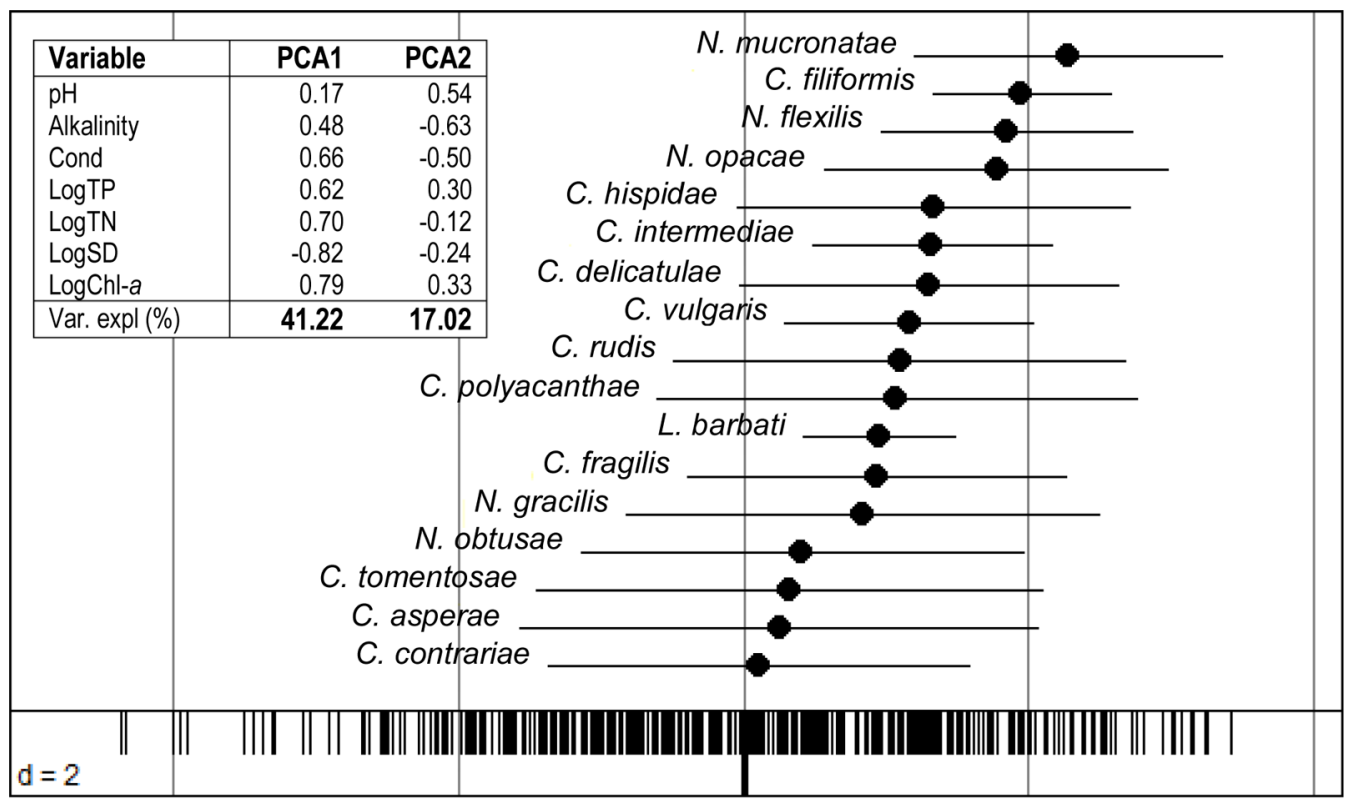

OMI1 (67.61\%)

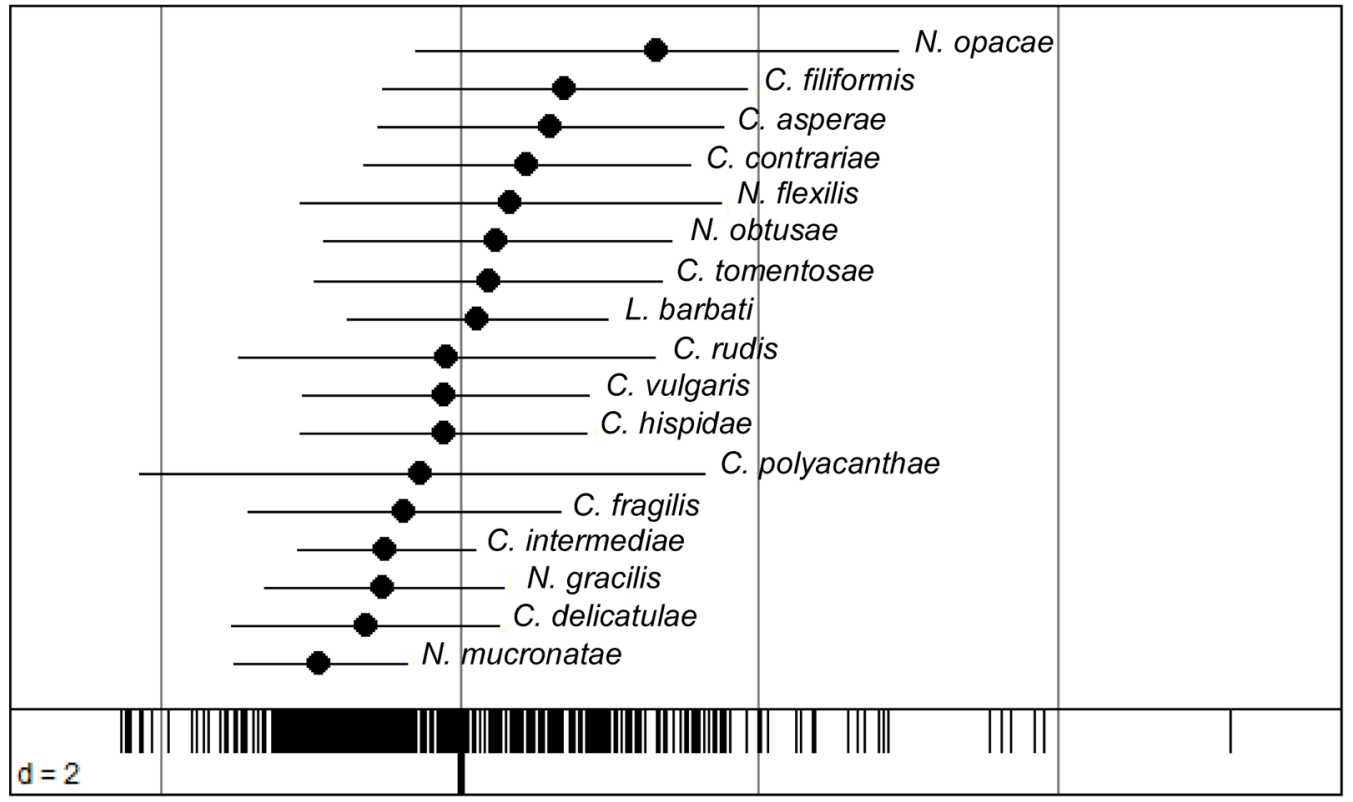

OMI2 (16.09\%)

Fig. 3. Niche ordination of the 17 charophyte communities along the eutrophication (OMI1) and alkalinity gradient (OMI2) determined by Outlying Mean Index method; niche ordination graph for all 65 hydrophyte communities among which the positions of charophytes were analysed is presented in Figure S1.

communities, i.e., C. tomentosae, C. asperae, C. contrariae and $N$. obtusae, with a high tolerance (broad tolerance towards eutrophication) and low marginality can be considered generalists. Their niche positions least deviated from the mean trophic condition within the study region (Fig. 3); thus, the presence of these communities may indicate relatively fertile waters. Interestingly, $N$. obtusa and $C$. tomentosa, species which form the two most frequent and abundant communities with the lowest marginality in this study, from the Nordic countries and Switzerland were reported as rare and of high marginality (Auderset Joye and Rey-Boissezon, 2015; Baastrup-Spohr et al., 2015). Nitellopsis obtusa is currently classified as a boreal species with a distribution limited almost exclusively to large and deep lakes (Auderset Joye and Rey-Boissezon, 2015; Stewart and Church, 1992) and is considered rare or declining in its native range (Larkin et al., 2018). In Poland, however, this species is common and widespread, and its communities inhabit lakes representing a wide spectrum of morphological and trophic conditions, including those with a lower than good ecological status 
Table 2. Results of the OMI analysis for 17 charophyte communities in Polish lakes identified in more than three surveys in the database $(n=404)$; communities arranged according to the OMI values in descending order. OMI - Outlying Mean Index; Tol - Tolerance Index; Rtol residual tolerance. OMI analysis was performed including all hydrophyte communities $(n=65)$ identified in 692 surveys of Polish lowland lakes; full names and statistics for all other hydrophyte communities are presented in Table S2.

\begin{tabular}{|c|c|c|c|c|c|c|c|}
\hline \multirow[t]{2}{*}{ Charophyte community } & \multirow[t]{2}{*}{$n$} & \multirow[t]{2}{*}{$F(\%)$} & \multicolumn{5}{|c|}{ Results of the OMI analysis } \\
\hline & & & Inertia & OMI & Tol & Rtol & $p$-value \\
\hline Nitelletum mucronatae & 7 & 1.7 & 10.46 & 8.48 & 0.99 & 0.99 & 0.038 \\
\hline Nitelletum opacae & 7 & 1.7 & 10.13 & 6.85 & 0.94 & 2.33 & 0.024 \\
\hline Nitelletum flexilis & 37 & 9.2 & 7.31 & 5.31 & 0.62 & 1.37 & 0.024 \\
\hline Charetum filiformis & 25 & 6.2 & 7.04 & 5.12 & 0.45 & 1.46 & 0.019 \\
\hline Lychnothamnetum barbati & 4 & 1.0 & 5.72 & 4.84 & 0.01 & 0.88 & 0.860 \\
\hline Charetum hispidae & 13 & 3.2 & 6.30 & 3.76 & 1.14 & 1.39 & 0.567 \\
\hline Nitelletum gracilis & 12 & 3.0 & 9.76 & 3.71 & 1.94 & 4.11 & 0.029 \\
\hline Charetum delicatulae & 82 & 20.3 & 6.22 & 3.53 & 1.05 & 1.64 & 0.001 \\
\hline Charetum intermediae & 24 & 5.9 & 5.73 & 3.31 & 0.28 & 2.15 & 0.113 \\
\hline Charetum polyacanthae & 11 & 2.7 & 9.25 & 2.91 & 2.22 & 4.12 & 0.030 \\
\hline Charetum vulgaris & 27 & 6.7 & 5.47 & 2.78 & 0.66 & 2.03 & 0.044 \\
\hline Charetum rudis & 43 & 10.6 & 6.25 & 2.65 & 1.31 & 2.28 & 0.007 \\
\hline Charetum fragilis & 187 & 46.3 & 5.14 & 2.27 & 0.95 & 1.92 & 0.001 \\
\hline Nitellopsidetum obtusae & 303 & 75.0 & 6.17 & 1.42 & 1.17 & 3.57 & 0.001 \\
\hline Charetum contrariae & 46 & 11.4 & 5.66 & 1.38 & 0.62 & 3.66 & 0.025 \\
\hline Charetum asperae & 53 & 13.1 & 6.56 & 1.30 & 1.51 & 3.75 & 0.026 \\
\hline Charetum tomentosae & 199 & 49.3 & 5.86 & 1.18 & 1.50 & 3.18 & 0.001 \\
\hline
\end{tabular}

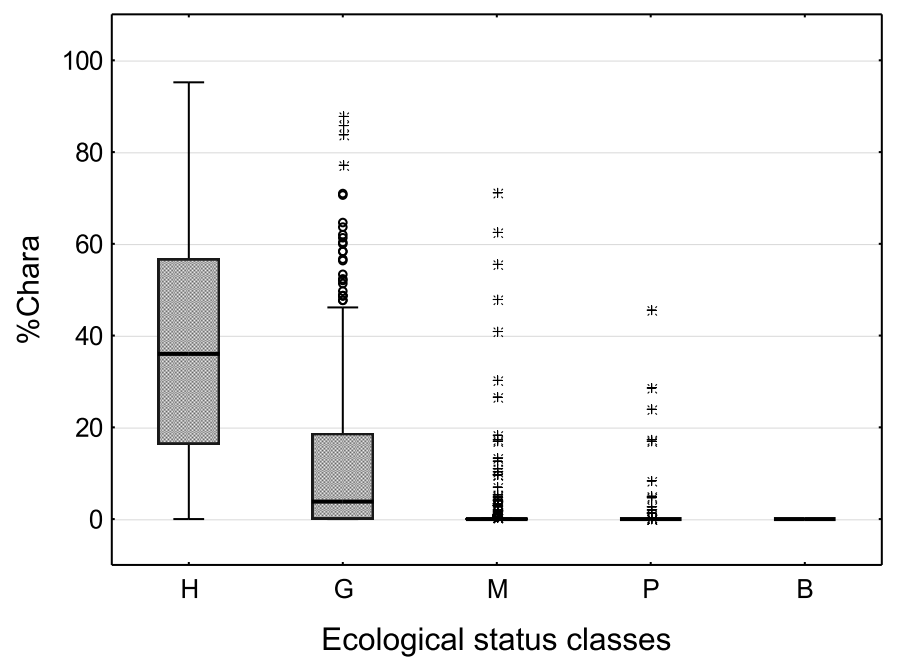

Fig. 4. Proportion of the phytolittoral area covered by charophyte communities (\%Chara) in lake-surveys classified into high $(\mathrm{H})$, good $(\mathrm{G})$, moderate $(\mathrm{M})$, poor $(\mathrm{P})$ and bad $(\mathrm{B})$ ecological status classes based on the Ecological Status Macrophyte Index $(n=739$ lakesurveys); box-plots represent quartile range (box) with median (line), non-outlying range (whiskers), extreme (circles) and outlying (star) values.

(Fig. 5). In contrast, in the North America, in its non-native range, $N$. obtusa is of increasing concern as an invasive species with rapid spread and high ability to form large, nearly monotypic stands resistant to control (Larkin et al., 2018). This may result from the high adaptative abilities of $N$. obtuse suggested by Boissezon et al. (2018).
The communities of $C$. contraria, $C$. globularis and C. vulgaris, which were recorded in a significant number of lakes in Poland, are formed by species recognised as "the greatest generalists" among stoneworts, with the smallest specialisation and the highest probability of widespread occurrence in Europe (Baastrup-Spohr et al., 2015; ReyBoissezon and Auderset Joye, 2015). In this study, these communities indeed exhibited relatively low marginality (niches located close to the mean habitat conditions) but also low tolerance, indicating narrow habitat niches. In the case of communities with a low OMI and low Tol, it can be anticipated that their niche breadth is shaped by factors other than nutrients, i.e., related to the water buffer capacity. Other cases address communities with a relatively high marginality (OMI $>2.5$ in this study) and also a high tolerance (Tol $>1.0)$, i.e., C. polyacanthae, C. delicatulae. C. hispidae and N. gracilis. They occur in trophic conditions shifted towards less eutrophic within the study region, though they exhibit a relatively high variance of these conditions.

The relatively close position and similar breath of habitat niches of most analysed charophyte communities analysed in this study may result from the spatial separation in sampling locations of macrophytes and water physicochemistry. Relating characteristics of pelagic waters with conditions of littoral biota may reduce the capability to capture the local peculiarities associated with the presence/absence of individual communities. This can explain the imperfect alignment between the trophic state of a lake and the local representativeness of charophyte syntaxa. On the other hand, the high spatial variability of abiotic conditions in the littoral zone together with the local modifying effect of macrophyte, particularly charophyte, patches on water quality (van Donk and van de Bund, 2002) make the links between habitat and 


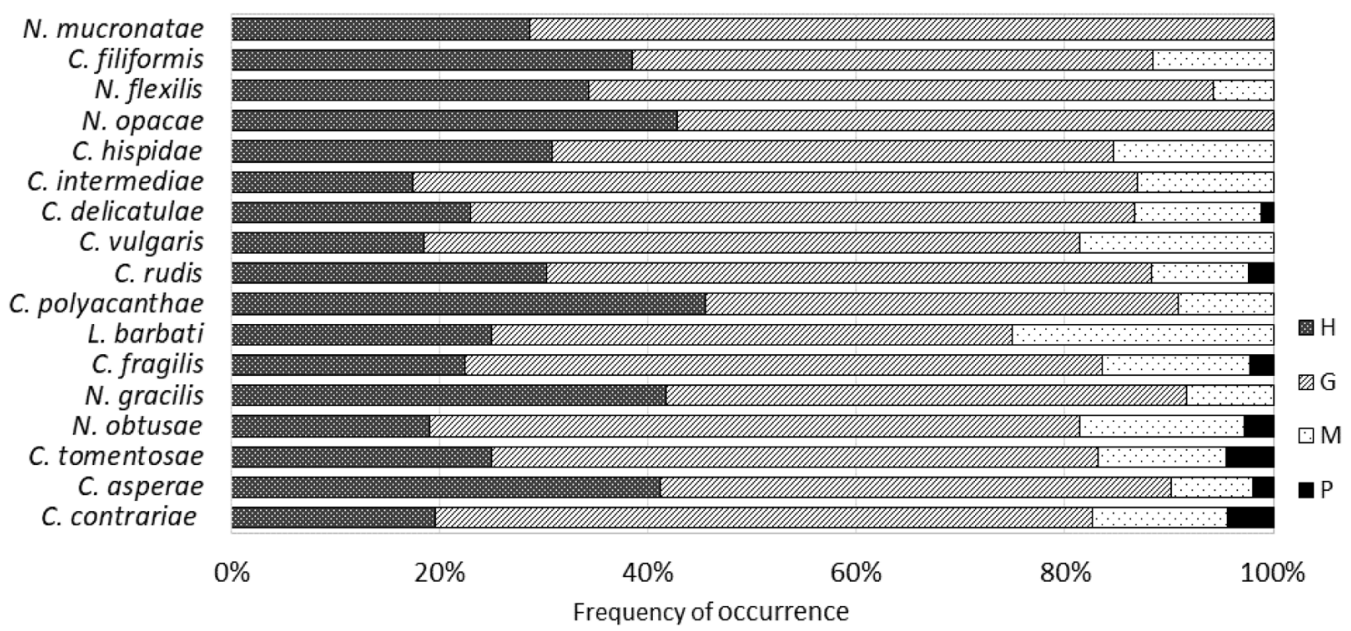

Fig. 5. Proportion of lake-surveys where charophyte communities were identified $(n=404)$ classified into high $(H)$, good $(G)$, moderate $(M)$ and poor $(\mathrm{P})$ ecological status classes based on the Ecological Status Macrophyte Index; 17 communities identified in more than three records are presented and ordered according to the OMI value in ascending order.

biota extremely complex and difficult to interpret, particularly in the context of ecological status assessment. Therefore, corresponding "overall" physicochemical status with conditions of biological assemblages inhabiting different functional lake zones is widely used and commonly accepted in WFD-compliant assessments.

Seven charophyte syntaxa were recorded in lakes with a poor ecological status (Fig. 5), and they were those with the lowest marginality (Tab. 2). According to the ESMI method, in lakes with a poor status, the macrophyte syntaxonomic diversity or colonisation depth or cover (or all of the above) are low, indicating adverse changes in biological assemblages. However, charophytes have been reported even from such ecosystems. Most of the other charophyte communities occurred in lakes with a moderate status. Thus, in the case of charophytes, except for communities that appeared to be rare and sensitive, those that were demonstrated 'generalists' are relatively common and cannot be considered indicative of good ecological conditions. Although it is much more likely that in lakes with a high or good ecological status, charophyte communities will be present (Poikane et al., 2018; Fig. 4), their presence does not necessarily guarantee good ecological conditions. On the other hand, ecosystems not inhabited by rare species may represent a high status, provided that the structure and composition of their macrophyte communities are healthy.

The ecological status of an ecosystem, although closely related to the trophic state, is not its equivalent. The first status determines the level of nutrient enrichment, while the latter evaluates the health of an ecosystem based on the structure and functioning of aquatic assemblages. In naturally eutrophic conditions typical of the Central European Lowlands, waters are inhabited by eurytopic species, and most taxa have similar niches along the trophic gradient. In such ecosystems, for bioassessment purposes, taxonomic diversity seems to be more relevant than composition. Moreover, other features of the macrophyte assemblage should be considered, i.e., the maximum depth of colonisation and/or macrophyte coverage (Søndergaard et al., 2013; Kolada, 2014).
Obviously, charophytes contribute to the syntaxonomic diversity $\mathrm{H}$, but they also significantly contribute to the littoral extent, as lakes with a high abundance of charophyte communities also had high $C_{\max }$. The capability of charophytes to form extensive littoral lawns derives from their physiological and morphological adaptations to the effective exploitation of underwater light, hence their ability to colonise deeper parts of the phytolittoral zone than higher plants (Middleboe and Markager, 1997; Schwarz et al., 2002; Azzella et al., 2017). Moreover, due to the capability to modulate the surrounding space by regulating the availability of nutrients and stabilising role in maintaining high water transparency (van Donk and van de Bund, 2002), macrophytes, and the charophyte communities in particular (including the 'generalists'), strongly contribute to supporting good ecological conditions. Therefore, in lowland naturally eutrophic lakes, the extraordinary role of charophytes in the assessment of the ecological status can be interpreted through their significant contribution to development of the phytolittoral zone and central role in regulating water quality. Taking into account the different spatial scales of investigation in bioassessment systems, i.e., the overall assessment of a lake versus the conditions of the single vegetated belts in the littoral, it is likely that the structure of the charophyte vegetation as a whole and not the presence/absence of the individual syntaxa can better reflect the overall state of ecological quality of a colonised lake.

\section{Supplementary Material}

Table S1. Main geographical, hydromorphological and physicochemical characteristics of the lakes inhabited (Chara lakes) and not inhabited by the charophyte communities (Non-Chara lakes).

Table S2. List of hydrophyte communities identified in 692 surveys performed in the lowland lakes in Poland surveyed in the years 2005-2015 and the results of the OMI analysis. 
Table S3. Typical values (medians) of the main environmental parameters in the lakes where charophyte communities were found.

Figure S1. Niche ordination of 65 hydrophyte communities identified in 692 surveys of the lowland lakes along the axis 1 of the Outlying Mean Index analysis; key to the name abbreviations is given in Table S2; open circles - charophyte communities; closed circles - other hydrophyte communities.

The Supplementary Material is available at https://www.kmaejournal.org/10.1051/kmae/2021030/olm.

Acknowledgments. This study was supported by the grant of the Ministry of Science and Higher Education for the statutory activity of the Institute of Environmental Protection - National Research Institute. The Chief Inspectorate for Environmental Protection in Poland is kindly acknowledged as the provider of monitoring data on water quality and the aquatic vegetation of a substantial part of the lakes analysed in this study. Biological and physicochemical data on 11 lakes were acquired from the Project 'deWELopment', supported by a grant from Norway through the Norwegian Financial Mechanism within the Polish-Norwegian Research Fund (PNRF-220-AI-1/07). Prof. Mariusz Pełechaty and Dr. Andrzej Pukacz are kindly acknowledged for their substantial support in the taxonomical identification of charophytes in lakes surveyed by the author. Special thanks go to Piotr Ćwiakowski from LabMasters for his technical support in using R scripts and to my colleague Sebastian Kutyła for preparing the map included in Figure 1 in this study.

\section{References}

Auderset Joye D, Castella E, Lachavanne JB. 2002. Occurrence of Characeae in Switzerland over the last two centuries (1800-2000). Aquat Bot 72: 369-385.

Auderset Joye D, Rey-Boissezon D. 2015. Will charophyte species increase or decrease their distribution in a changing climate? Aquat Bot 120: 73-83.

Azzella MM. 2014. Italian volcanic lakes: a diversity hotspot and refuge for European charophytes. J Limnol 73: 502-510.

Azzella MM, Abdelahad N. 2011. Une station actuelle de Lychnothamnus barbatus (Charophyceae) en Italie Centrale: le Lac de Martignano (Latium). Cryptogamie Algol 32: 301-307.

Azzella MM, Bresciani M, Nizzoli D, Bolpagni R. 2017. Aquatic vegetation in deep lakes: Macrophyte co-occurrence patterns and environmental determinants. J Limnol 76: 97-108.

Baastrup-Spohr L, Iversen LL, Borum J, Sand-Jensen K. 2015. Niche specialization and functional traits regulate the rarity of charophytes in the Nordic countries. Aquat Conserv 25: 609-621.

Baastrup-Spohr L, Iversen LL, Dahl-Nielsen J, Sand-Jensen K. 2013. Seventy years of changes in the abundance of Danish charophytes. Freshw Biol 58: 1682-1693.

Blaženčić J, Stevanović B, Blaženčić Z, Stevanović V. 2006b. Red data list of charophytes in the Balkans. Biodivers Conserv 15: 3445-3457.

Blaženčić J, Stevanović B, Blaženčić Z, Stevanović V. 2006a. Distribution and ecology of charophytes recorded in the West and Central Balkans. Cryptogamie Algol 27: 311-322.

Blindow I. 1988. Phosphorus toxicity in Chara. Aquat Bot 32: 393-395.

Blindow I. 1992. Decline of charophytes during eutrophication comparison with angiosperms. Freshw Biol 28: 9-14.
Blindow I, Hargeby A, Andersson G. 2002. Seasonal changes of mechanisms maintaining clear water in shallow lake with abundant Chara vegetation. Aquat Bot 72: 315-334.

Boissezon A, Auderset Joye D, Garcia T. 2018. Temporal and spatial changes in population structure of the freshwater macroalga Nitellopsis obtusa (Desv.) J. Groves. Botany Lett 165: 103-114.

Braun-Blanquet J. 1964. Pflanzensoziologie. Wien, New York: Springer.

Brzeg A, Wojterska M. 2001. Plant communities in Wielkopolska: the state of knowledge and threats. p. 39-110. In: Wojterska M. ed. Flora and Vegetation of Wielkopolska and South-Pomerania Lakeland. Guide book of 52. Reunion of Polish Botanical Society, Poznań (in Polish).

Brzozowski M, Pelechaty M, Pietruczuk K. 2018. Co-occurrence of the charophyte Lychnothamnus barbatus with higher trophy submerged macrophyte indicators. Aquat Bot 151: 51-55.

Ciecierska H, Kolada A. 2014. ESMI: a macrophyte index for assessing the ecological status of lakes. Environ Monit Assess 186: 5501-5517.

Crawford SA. 1977. Chemical, physical and biological changes associated with Chara succession in farm ponds. Hydrobiologia 55: 209-217.

Dąmbska I. 1964. Charophyta - ramienice. In: K. Starmach (ed.), Freshwater flora of Poland. Vol 13. PWN, Warsaw (in Polish).

Dengler J, Chytry M, Ewald J. 2008. Phytosociology. In: S.E. Jřrgensen, B.D. Fath (eds.), General Ecology. Encyclopedia of Ecology. Vol. 4, Oxford: Elsevier, pp. 2767-2779.

Dolédec S, Chessel D, Gimaret-Carpentier C. 2000. Niche separation in community analysis: a new method. Ecology 81: 2914.

EU. 2000. Directive 2000/60/EC of the European Parliament and of the Council of 23 Oct. 2000 establishing a framework for Community action in the field of water policy. OJEC L 327/1.

Hernández-Fariñas T, Bacher C, Soudant D, Belin C, Barillé L. 2015. Assessing phytoplankton realized niches using a French national phytoplankton monitoring network. Estuar Coast Shelf Sci 159: $15-27$.

IUCN 2001. IUCN Red List Categories and Criteria. IUCN: Gland and Cambridge.

Jensen S. 1977. An objective method for sampling the macrophyte vegetation in lakes. Vegetatio 33: 107-118.

Karasiewicz S. 2018. Subniche Documentation for the Within Outlying Mean Indexes calculations (WitOMI). Retrieved from https://github. com/KarasiewiczStephane/WitOMI (accessed May 2021).

Karasiewicz S, Dolédec S, Lefebvre S. 2017. Within outlying mean indexes: refining the OMI analysis for the realized niche decomposition. PeerJ 5: e 3364.

Kleyer M, Dray S, Bello F, Lepš J, Pakeman RJ, Strauss B, Lavorel S. 2012. Assessing species and community functional responses to environmental gradients: which multivariate methods? J Veg Sci 23: $805-821$.

Kolada A. 2009. Is the Lychnothamnus barbatus (Meyen) Leonhardi 1863 a good indicator of water quality? A new locality of the species in Górskie Lake near Gostynin (Central Poland). Oceanol. Hydrobiol. St. 38, Serie: Phycologica Polonica 2: 39-43.

Kolada A. 2010. The use of aquatic vegetation in the lake assessment: testing the sensitivity of macrophyte metrics to anthropogenic pressures and water quality. Hydrobiologia 656: 133-147.

Kolada A. 2014. The effect of lake morphology on aquatic vegetation development and changes under the influence of eutrophication. Ecol Indic 38: 282-293.

Kolada A, Ciecierska H, Ruszczyńska J, Dynowski P. 2014a. Sampling techniques and inter-surveyor variability as sources of uncertainty in Polish macrophyte based metric for lake ecological status assessment. Hydrobiologia 737: 256-279.

Kolada A, Willby N, Dudley B, Nõges P, Søndergaard M, Hellsten S, Karus K. 2014b. The applicability of macrophyte compositional 
metrics for assessing eutrophication in European lakes. Ecol Indic 45: 407-415.

Krause W. 1981. Characeen als Bioindikatoren für den Gewässerzustand. Limnologica 13: 399-418.

Krause W. 1997. Charales (Charophyceae). In: H. Ettl, G. Gärtner, H. Heynig, D. Mollenhauer (eds). Süsswasserflora von Mitteleuropa. Gustav Fisher: Stuttgart; 1-202 (in German).

Kufel L, Kufel I. 2002. Chara beds acting as nutrient sinks in shallow lakes - a review. Aquat Bot 72: 249-260.

Kufel L, Ozimek T. 1994. Can Chara control phosphorus cycling in Lake Luknajno (Poland). Hydrobiologia 275/276: 277-283.

Lambert-Servien E, Clemenceau G, Gabory O, Douillard E, Haury J. 2006. Stoneworts (Characeae) and associated macrophyte species as indicators of water quality and human activities in the Pays-dela-Loire region, France. Hydrobiologia 570: 107-115.

Larkin DJ, Monfils AK, Boissezon A, Sleith RS, Skawinski PM, Welling CH, Karol KG. 2018. Biology, ecology, and management of starry stonewort (Nitellopsis obtusa; Characeae): a Red-listed Eurasian green alga invasive in North America. Aquat Bot 148: 15-24.

Matuszkiewicz W. 2002. A guide book to identification plant communities in Poland. Warsaw: PWN (in Polish).

Meynard CN, Pillay N, Perrigault M, Caminade P, Ganem G. 2012. Evidence of environmental niche differentiation in the striped mouse (Rhabdomys sp.): inference from its current distribution in southern Africa. Ecol Evol 2: 1008-1023.

Middleboe AL, Markager S. 1997. Depth limits and minimum light requirements of freshwater macrophytes. Freshw Biol 37: 553-568.

Ozimek T, Kowalczewski A. 1984. Long-term changes of the submerged macrophytes in eutrophic lake Mikołajskie (North Poland). Aquat Bot 19: 1-11.

Palomares F, Fernández N, Roques S, Chávez C, Silveira L, Keller C, Andrados B. 2016. Fine-scale habitat segregation between two ecologically similar top predators. PLoS ONE 11: e 0155626.

Pełechaty M, Brzozowski M. 2016. Ecological plasticity of Lychnothamnus barbatus: implications for biomonitoring of contemporary aquatic environments and palaeoenvironmental reconstructions. Book of abstracts from Conference: $\mathrm{XXXV}^{\text {th }}$ International Conference of the Polish Phycological Society 'Algae in anthropogenically transformed ecosystems', Łódź-Stryków, Poland.

Pełechaty M, Pronin E, Pukacz A. 2014. Charophyte occurrence in Ceratophyllum demersum stands. Hydrobiologia 737: 111-120.

Pełechaty M, Gąbka M, Sugier P, Pukacz A, Chmiel S, Ciecierska H, Owsianny PM. 2009. Lychnothamnus barbatus in Poland: habitats and associations. Charophytes 2: 13-18.

Pełechaty M, Pukacz A. 2008. Guide to identify charophyte species (Characeae) in rivers and lakes. Biblioteka Monitoringu Środowiska, Warszawa (in Polish).

Poikane S, Portielje R, Denys L, Elferts D, Kelly M, Kolada A, van den Berg M. 2018. Macrophyte assessment in European lakes: Divergent approaches but convergent views of 'good' ecological status. Ecol Indic 94: 185-197.

Portielje R, Bertrin V, Denys L, Grinberga L, Karottki I, Kolada A, Poikane S. 2014. Water Framework Directive Intercalibration Technical Report. Central Baltic Lake Macrophyte Ecological Assessment Methods. Publications Office of the European Union, Luxembourg, Ispra.
Rey-Boissezon A, Auderset Joye D. 2015. Habitat requirements of charophytes - evidence of species discrimination through distribution analysis. Aquat Bot 120: 84-91.

Schwarz AM, de Winton M, Hawes I. 2002. Species-specific depth zonation in New Zealand charophytes as a function of light availability. Aquat Bot 72: 209-217.

Schwarz AM, Hawes I, Hovard-Williams C. 1999. Mechanisms underlying the decline and recovery of a Characean community in fluctuating light in a large oligotrophic lake. Aust J Bot 47: 325-336.

Siemińska J, Bąk M, Dziedzic J, Gąbka M, Gregorowicz P, Mrozińska T, Witkowski A. 2006. Red list of the algae in Poland. In: Z. Mirek, K. Zarzycki, W. Wojewoda, Z. Szeląg (eds.), Red list of plants and fungi in Poland. Kraków: Szafer Institute of Botany, Polish Academy of Sciences.

Søndergaard M, Johansson LS, Lauridsen TL, Jørgensen TB, Liboriussen L, Jeppesen E. 2010. Submerged macrophytes as indicators of the ecological quality of lakes. Freshw Biol 55: 893-908.

Søndergaard M, Phillips G, Hellsten S, Kolada A, Ecke F, Mäemets H, Mjelde M, Azzella MM, Oggioni A. 2013. Maximum growing depth of submerged macrophytes in European lakes. Hydrobiologia 704: 165-177.

Soszka H, Ochocka A. 2011. Lakes. Supporting physicochemical elements. p. 249-256. In: H. Soszka (ed.), Ecological status assessment of the waters in the Wel river catchment. Guidelines for integrated assessment of ecological status of rivers and lakes to support river basin management plans. Institute of Inland Fisheries, Olsztyn (in Polish with English summary).

StatSoft Inc. 2011. STATISTICA (data analysis software system), version 10. www.statsoft.com.

Stewart NF, Church JM. 1992. Red Data Book of Britain and Ireland: Stoneworts. Joint Nature Conservation Committee, Peterborough $235 \mathrm{p}$.

Sugier P, Pełechaty M, Gąbka M, Owsianny PM, Pukacz A, Ciecierska H, Kolada A. 2010. Lychnothamnus barbatus: global history and distribution in Poland. Charophytes 2: 19-24.

Thuiller W, Lavorel S, Midgley G, Lavergne S, Rebelo T. 2004. Relating plant traits and species distributions along bioclimatic gradients for Leucadendron taxa. Ecology 85: 1688-1699.

Urbaniak J, Gąbka M. 2014. Polish Charophytes. An illustrated guide to identification. Wrocław: Wrocław University of Environmental and Life Sciences Press.

van den Berg MS. 1999. Charophyte colonization in shallow lakes: processes, ecological effects and implications for lake management. PhD Thesis, Free University, Amsterdam 138 p.

van den Berg MS, Scheffer M, van Nes E, Coops H. 1999. Dynamics and stability of Chara sp. and Potamogeton pectinatus in a shallow lake changing in eutrophication level. Hydrobiologia 408/409: 335-342.

van Donk E, van de Bund WJ. 2002. Impact of submerged macrophytes including charophytes on phyto- and zooplankton communities: allelopathy versus other mechanisms. Aquat Bot 72: 261-274.

Vesić A, Blaženčić J, Šinžar-Sekulić J. 2016. Contribution to knowledge of the Charophytes (Charales) of Vojvodina (Serbia) 20 years after the first review. Bot Serb 40: 237-247.

Willner W. 2006. The association concept revisited. Phytocoenologia 36: 67-76.

Cite this article as: Kolada A. 2021. Charophyte variation in sensitivity to eutrophication affects their potential for the trophic and ecological status indication. Knowl. Manag. Aquat. Ecosyst., 422, 30. 